\title{
Nineteenth century \\ defamation: was it a law of \\ the press?
}

by Paul Mitchell

The author considers the relationship between defamation and the press.

$\mathrm{I}$ $\mathrm{f}$ the title of this article had referred to the twenty-first century, rather than the nineteenth, the question it asks could be easily answered. The twenty-first century law of defamation is clearly a law of the press: it is taught almost exclusively in courses on media law, for instance, and all the cases seem to be against media, predominantly newspaper, defendants. At a more fundamental level, the content of the current law is strongly influenced by judges' perceptions of the press. To take one prominent instance, the emergence of a defence for the publication of matter of public interest has made express use of a standard of "responsible journalism" (see Reynolds V Times Newspapers Limited [2001] 2 AC 127). Similarly, the House of Lords in the recent case of Jameel $v$ Wall Street Journal Europe Sprl [2007] 1 AC 359 stated that an editor's assessment of the quality of the information published, and its importance, should be given weight. This deference to existing journalistic standards and practice makes defamation not only a law relating to the press, but, more controversially, a law partly created by the press.

The nineteenth century relationship between the law and the press is, on the face of it, very different. As a matter of classification, throughout the century defamation was seen as part of the law of tort. Only in the 1890s do we start to see works such as Fisher and Strahan's excellent The Law of the Press (First edition London, 1891; second edition London, 1898) attempting to place defamation in a newspaper law context. Similarly, press defendants had nothing like the monopoly on litigation of today's media corporations. More fundamentally, key developments in the law occurred in cases having no press connections at all. Thus, the split into libel and slander came about in Thorley v Lord Kerry (1812) 4 Taunt 355, a case over a defamatory letter. Qualified privilege was created in Toogood v Spyring (1834) 1 CM\&R 181 following a master's public criticism of a servant. And the fragmentation of malice in Bromage ${ }_{v}$ Prosser (1825) 4 B\&C 247, arguably the most important development in defamation in that, or any other century, arose out of a conversation between one bank customer and another.

We must also recognise, of course, that although the law of defamation affected the press, it provided a very limited way of regulating only one aspect of newspaper activity. Other matters such as contempt of court, and the infringement of intellectual property rights had to be dealt with by other bodies of law. Defamation could only ever be "a" law of the press, not "the" law. And we must also recognise that there were (and still are) some big gaps, where there was no legal mechanism to deter very dubious practices. Perhaps the most vivid exposure of these gaps is provided by Anthony Trollope, in his novel The Way We Live Now (1875). As part of the novel's general theme of the corruption and dishonesty of 1870 s society, the author turned his attention to the unscrupulousness of the press. Thus, the novel opens with Lady Carbury, a hack authoress, writing to three newspaper editors to solicit undeservedly favourable reviews of her latest mediocre book. She is partly successful. Later on, when Melmotte, the novel's menacing villain, is put forward as a Conservative candidate for Westminster, Trollope has one of his fictional newspapers, "The Morning Breakfast Table" lavish extravagant praise on him.

Trollope goes on to comment that:

they who are concerned in the manufacture of newspapers are well aware that censure is infinitely more attractive than eulogy, - but they are quite as well aware that it is more dangerous. No proprietor or editor was ever brought before the courts at the cost of ever so many hundred pounds, - which if things go badly may rise to several thousands, - because he had attributed all but divinity to some very poor specimen of mortality. No man was ever called upon for damages because he had attributed grand motives. It might be well for politics and literature and art, - and for truth in general, if it was possible to do so. But a new law of libel must be enacted before such salutary proceedings can take place (A Trollope, The Way We Live Now (Oxford University Press, 1982) Book 1, Chapter XLIV at 415-16). 
As a matter of legal analysis, Trollope was, of course, correct. Anyone negatively affected by praise of another might conceivably have had a claim for malicious falsehood, but the requirements of that tort - including proof of malice and of damage - would in practice have prevented any remedy being obtained. But, as Trollope suggests, manufactured praise had the same tendency to mislead and corrupt as manufactured criticism: in the novel, Melmotte wins the election.

So, when we consider the nineteenth century relationship between defamation and the press, we must bear in mind that we are considering only the interaction of selected aspects of both subjects. But, though the influence of the press on defamation was less all-pervasive than it is today, it was, I shall argue, of some importance throughout the century, and its influence increased as the century wore on. But the form of that influence, and its effects, fluctuated, and occasionally backfired. In order to assess that influence more closely we must now distinguish between legislation and common law.

\section{LEGISLATION}

Right from the start of the century, legislators were clear that the law of defamation should be seen in the context of the press. Thus, for instance, following the division of the tort into libel and slander by the Court of Common Pleas in 1812, Brougham began a Parliamentary campaign to assimilate slander to libel (For details see P Mitchell, "The Foundations of Australian Defamation Law" (2006) 28 Sydney Law Review 477). Though his proposal would not be limited to the press, indeed it would have no effect on the press at all (which would remain governed by the stricter rules of libel), the measure was included in a Bill "for securing the Liberty of the Press and preventing the abuse thereof". Brougham's Bill failed, and it was succeeded by a series of equally unsuccessful attempts to effect reform. Those later Bills also raised the question of limiting the defence of justification to situations where publication of the matter was for "the public benefit". One of the most striking themes in these debates and proposals was the prominence given to the press. Thus, for instance, Daniel O'Connell, a former journalist himself, opposed the assimilation of slander to libel. Rather, he argued, the assimilation should be the other way, because the categories of slander were fixed, and the press should be able to predict with confidence what would or would not incur liability (Comerford, "O'Connell, Daniel (17751847)" Oxford Dictionary of National Biography (Oxford University Press, 2004 online edn). A Select Committee appointed in 1834 was instructed to consider the effect of the law of defamation on the press. The committee never reported, but the 1843 committee, chaired by Lord Campbell (himself a former journalist, though he had been careful to hide the fact) heard extensive evidence about how the law affected the press.
No evidence was given to the committee by O'Connell previously calling Lord Campbell "a tool of the base and bloody Whigs" had not ingratiated him with the chairman (see G Jones and V Jones, "Campbell, John first Baron Campbell of St Andrews (1779-1861)"Oxford Dictionary of National Biography (Oxford University Press, 2004, online edn). O'Connell's absence was rather a pity because, as it turned out, he was going further, and demanding more, than the newspaper editors themselves. For instance, Stanley Lees Giffard, the editor of the Standard newspaper, stated that his "First Objection" to the current law was that "you have no power of negativing the Imputation of legal Malice on the Trial" (see Report from the Select Committee of the House of Lords appointed to consider the Law of Defamation and Libel, July 1843 for this and subsequent statements). He went on to say that truth should not be a complete defence; rather, truth should be admitted only as evidence on the issue of malice. Furthermore, he was sceptical of the value of a public benefit test, commenting that he was "an Infidel about the Care of the public Good which is manifested in Libels."

The editor of the Examiner showed a similar lack of selfinterest. He, too, would have altered the rule that truth was a complete defence, preferring instead that the truth should be received by the jury "for as much as it is worth." Again, he saw the question of truth as subordinate to the question of malice. A different approach was advocated by Johnson Gedge, the Secretary to the Society of Provincial Newspaper Proprietors. He argued that criminal libel and civil libel should rest on different principles: criminal libel should be based on malice, whilst civil libel should turn on "Injury proved or reasonably to be inferred." Yet another suggestion came from John Robertson, the editor of the London and Westminster Review, who said:

Let all Forms of Law open a clear Path to going before a Jury to ascertain whether the Fact published was true; and, in the second place, whether if it was true the Publication of it was justifiable.

An important factor in answering the second question, he said, was "whether the Writer was an anonymous Writer, or whether he, like a Man discharging a public Duty, and doing what was right, put his name, or his understood literary Signature, to what he said".

Several points can be made about the range of views put before the Select Committee. First is the sheer divergence of views: clearly we cannot say that there was a (unified) press view about what the law should be, or how it was defective. Second, we should note the lack of self-interest: none of the editors or proprietors were prepared to endorse O'Connell's proposal to limit the range of actionable defamatory words to those in the slander categories. And all of the editors suggested abolishing truth as a complete defence, which was obviously against their interests. Third, there was no emphasis on certainty, or the avoidance of litigation. All the proposals for reform made 
by press interests to the Select Committee involved the application of very general tests: thus, the editor of the Standard proposed that juries should be directed to weigh up "the balance of malice"; the Secretary of the Society of Provincial Newspaper Proprietors suggested "injury proved, or reasonably to be inferred.” Both were formulae that almost guaranteed lengthy litigation; in both form and in content, these were exactly the kind of principles that later press representatives would regard as intolerably unjust and unpredictable.

That the newspaper editors and proprietors did so little to protect their own position in their evidence to the 1843 committee is surprising, and puzzling. We can only guess, but it may be that there is a clue to the mystery in the evidence of John Robertson, the editor of the London and Westminster Review. Towards the end of his evidence, Robertson seemed to veer off the subject of libel when he said that "the Recognition of Authors as a distinct Body and Profession of Importance would tend to create a higher moral Tone among them.” The perceived low status of authors was not exactly a novel sentiment, but Robertson's expression of it in the context of libel reform may explain the attitude adopted by his fellow editors. (For its important background role in a different legal arena see Charles Mitchell and Charlotte Mitchell, "Planché v Colburn (1831)" in C Mitchell and P Mitchell (ed), Landmark Cases in the Law of Restitution (Oxford, 2006) 65.

They perhaps wanted to demonstrate to the committee that they belonged to a respectable profession, which operated by the highest moral standards; and they were so confident in these high standards that they wanted them embodied in the law of libel. If this is right, the recurrent emphasis on malice in the editors' evidence becomes easier to understand: effectively they were saying - as an honourable profession, we are content to be judged by our motives. In other words, they wanted the rules of libel by which they were governed to reflect the status to which their profession aspired.

The 1843 committee proposed that slander should be assimilated to libel, and that justification should only be a defence where the matter was published for the public benefit. Ultimately these proposals came to nothing, although it is interesting to note that they were implemented in New South Wales. There much legislative emphasis was placed on the effect of limiting the defence of truth to matters of public benefit. In particular, the legislators hoped to curb the output of scurrilous newspapers, such as the recently defunct Satirist (see Sydney Morning Herald, June 10, 1846 at 3, col 3).

These early legislative initiatives show the close attention paid by Parliament to the effect of defamation on the press. But the content of the proposals also showed that the press was not going to get everything its own way: the 1843 Bill, as implemented in New South Wales in 1847, did not give effect to any of the views of the newspaper editors and proprietors who had given evidence to the Select Committee. The public benefit test in relation to truth, for instance, limited what could be published, and made it hard to predict what was permissible. The editor of the Sydney Morning Herald, who had to contend with these difficulties once Lord Campbell's proposals had been adopted in New South Wales, commented in his newspaper that the statute created "a perpetually varying Court of Conscience in the jury-box.”

Towards the end of the nineteenth century, however, the press influence in Parliament was becoming more powerful, and this increased influence was reflected in statutory reforms of libel law. Most important, for our purposes, are the Newspaper Libel and Registration Act of 1881 and the Law of Libel Amendment Act of 1888. Both statutes dealt with liability for reports of public meetings, a subject of obvious importance to the press. The common law position at the time was, interestingly, not so much opposed to such reports as uncertain. Until 1876 it had been consistently held that such reports were not protected, but in that year the Divisional Court had held, in Purcell $v$ Sowler (1876) 1 CPD 781, that such reports would be protected if they related to both an individual and a subject-matter of national importance. The conduct of the medical officer of the Altrincham poor-law union failed both criteria.

In the Court of Appeal ((1877) 2 CPD 215), however, Cockburn CJ had taken a different approach. In his view, national importance of either person or subject-matter was not necessary - public interest sufficed. But the Court of Appeal held, on the facts, that accusations of the kind made at the meeting should not have been reported before the claimant had an opportunity to respond to them, and for that reason there could be no defence for the newspaper. The stage seemed set for judicial exploration of the factors that would give rise to a defence.

The 1881 Act, introduced by Hutchinson, a newspaper proprietor, curtailed any such common law development: it created qualified privilege for reports of public meetings in newspapers where publication of the report was for the public benefit. The Act seemed to have resolved the problem, and generated only one reported case. In 1888, however, Parliament was persuaded to revisit the question, although not without protests from some Members that the new Bill was "promoted by a little knot of interested newspaper proprietors" (Hansard's Parliamentary Debates, $3^{\text {rd }}$ Series, vol 329 col 1552 (August 3, 1888)). In fact, the extent of press influence on the 1888 Act is quite extraordinary. In the House of Commons it was promoted by Sir Algernon Borthwick, Wilfrid Lawson and Charles Cameron. Borthwick was the proprietor of the Morning Post and President of the Press Newspaper Fund. Lawson was to go on to become the managing proprietor of the Daily Telegraph and Chairman of the Newspaper Proprietors Association. Cameron was the son of a 
newspaper proprietor, and the former editor of the North British Daily Mail.

More strikingly, the House of Lords made amendments to the Bill at the suggestion of the National Association of Journalists. The Bill was said by one approving peer to reflect "what the journalists wanted" (Hansard's Parliamentary Debates, $3^{\text {rd }}$ Series vol 329 col 1388 (August 3, 1888)). It is difficult to imagine the same announcement from a similar source today. What the journalists wanted, it turned out, was a list of meetings the reporting of which would give rise to a defence. That was basically what they got, although with the additional requirement of a public benefit test, which the Act's promoters had been opposed to. Today protection for reports of public meetings is set out in a very similar form, in the Defamation Act 1996.

What is particularly interesting about these two statutes is that the 1881 Act was considered so inadequate by the press, that a new Act, in such different terms was needed. On the face of it, the 1881 Act seemed to deliver everything that was required, but the problem was that it was expressed in terms of broad principle, rather than specific instances. Thus, there was scope for debate about what, exactly, made a public meeting public. There was also scope for debate about whether the report in general or the defamatory allegation in particular had to satisfy the public benefit test. In reality there was nothing to choose between the coverage of the 1881 Act and its 1888 successor from a legal analytical point of view, but the point seems to have been that the press did not want to embroil itself in legal analysis. Editors wanted to know what they could publish, not what the general principles were that governed the issue.

The point is perhaps best illustrated by the approach to defamation taken in the classic journalism primer written by A Baker and E Cope, Pitman's Practical Journalism and Newspaper Law (London, 1915). Lawyers traditionally expect any exposition of a tort to begin with the general rules of liability, then set out defences, and conclude with remedies. But in Pitman, the treatment of defamation begins with "Privileged Reports", a starting point which would be considered at best eccentric in a legal text. It sets out in some detail the position on reports of Parliamentary proceedings, extracts from Parliamentary papers, reports of judicial proceedings, coroners' inquests, local authority meetings, and public meetings. The general principles of defamation - the hatred, ridicule and contempt test, etc, get 10 lines at the end of the chapter. Clearly journalists and lawyers had very different perceptions both about how the law worked, and how it ought to be reformed.

\section{COMMON LAW}

I turn now to the common law. The overt control and design of legislation by press interests in the nineteenth century contrasts with the common law development of defamation in the same period. Of course, we would not expect to see factions of judges overtly supporting press interests, and other factions overtly opposing them. Nor does there seem to be any sign of covert factions, in for instance, split decisions, or courts disagreeing with each other. Indeed, at the start of the nineteenth century there seems to have been considerable judicial sympathy for the press, and recognition that it performed an important role. But this judicial sympathy could not, of course, be converted into overtly changing the law. Any alteration in the common law that was favourable to the press would have to be made by way of the traditional common law techniques of invoking established principles and reasoning by analogy.

Both the sympathy and the common law innovations to which it gave rise, are well illustrated in the emergence of the defence of fair comment in cases such as Tabart $v$ Tipper (1808) 1 Camp 350 and Carr v Hood (1808) 1 Camp 355 at the start of the nineteenth century. The courts started from the existing basic principle: liability required malice, but would be implied whenever defamatory words were spoken. They then took the view that a genuine critique of a work of literature, or a public performance, which contained defamatory allegations, could be seen as rebutting that presumption of malice, in the same way that a genuine critical reference about a servant given by his master to a potential new employer also rebutted the presumption. What was, essentially a new defence could be presented as nothing new, a mere application of established principle to new facts.

But, although the analysis being used to reach the result was traditional, the courts were careful to point out that, as a matter of policy, they were pleased with the outcome. Thus, for instance, in Tabart v Tipper Lord Ellenborough CJ commented (at 351-52) that "Fair discussion is essentially necessary to the truth of history, and the advancement of science." Literary, dramatic and other types of criticism were thereby protected, and, indeed encouraged. That this was a deliberate policy, not merely a happy case of the defamation rules getting the right answer, seems clear from the simultaneous recognition of the defence of fair use in copyright law (see R Burrell, "Reigning in Copyright Law: Is Fair Use the Answer?" [2001] Intellectual Property Quarterly 361).

A further important instance of judicial sympathy and encouragement could be seen later in the century, in the decision in Wason $v$ Walter, which recognised that fair and accurate reports of Parliamentary proceedings should be protected by qualified privilege. Part of the court's reasoning was based on an analogy with the protection given to reports of judicial proceedings. But, as with the development of the defence of fair comment, the decision in Wason v Walter (1868) LR 4 QB 73 was more than a mere elaboration of the existing principles applied to novel circumstances. A large part of the reasoning dealt with the balance of "general good over partial and occasional evil" 
that would result from permitting publication. This was an overtly policy-driven, indeed, utilitarian approach. It is also very tempting to link the decision with the expansion of the electoral franchise granted a year earlier, in 1867.

But judicial encouragement of press activity was not undiscriminating, and towards the end of the century judicial attitudes seemed to be cooling. This coincided with the appearance of a self-styled "new journalism", which T P O'Connor - one of its main exponents - wrote was distinguished by its "more personal tone" (see T P O'Connor, “The New Journalism” (1889) 1 The New Review 423). Invoking the historical precedents of Macaulay and Carlyle, O'Connor went on to justify this method:

"the desire for personal details with regard to public men is healthy, rational, and should be yielded to. Statesmen are not ciphers without form or blood or passion. Their utterances and acts are not pure intellectual secretions. If you want to know how such and such an act of weakness or folly is intelligible at some crisis in the history of a politician, you must have learned something more of the politician than you can get from the verbatim report of his speeches, or the colourless and dry language of his public documents."

These noble reasons, when applied in practice, however, yielded articles with titles such as "What the Queen Eats" R Pound and G Harmsworth, Northcliffe (London, 1959) 82 (listing the titles of articles in the first number of Answers to Correspondents). In the new style there was obviously greater potential for defamation than there had been under the old journalistic conventions. And this greater potential for defamation was combined with larger circulations, because the publications championing the new techniques were deliberately aimed at the large number of newly-literate readers who had benefited from the 1870 Education Act. Thus, Newnes' Tit-Bits, Harmsworth's Answers to Correspondents, Stead's Pall Mall Gazette and O'Connor's Star, to give some of the most prominent examples, all began publication in the 1880 s and 1890 s. But, as O'Connor realised, the new techniques were not universally wellreceived. Writing in 1889 he observed that:

There has recently grown up in the jury-box a spirit of savage hatred to journalism which has led to some very unjust verdicts and some scandalous damages. A portion of the public actually seem to imagine it is the desire and also the interest of a certain class of journalists to libel everybody they can. ... of the ordinary respectable journal no conception could be more incorrect ("The New Journalism" (1889) 1 The New Review 423 at 430-31).

The feelings of disquiet that O'Connor detected were not, I would suggest, confined to the jury-box. It seems to be no coincidence that when the House of Lords, in $E$ Hulton \& Co v Jones [1910] AC 20 introduced strict liability in defamation, it was in relation to an archetypal product of the new journalistic style. The House of Lords also declined to interfere with a very heavy award of damages against the newspaper concerned. Judicial caution could also be seen in the Court of Appeal, which introduced a negligence-based test for distributors in Emmens $v$ Pottle (1885) 16 QBD 354. That test was stricter than the test previously had been for such defendants, and Bowen LJ seemed to have a particular kind of publication in mind when he said that a distributor would be liable if he knew that the work in question was "likely" to contain a libel.

Applied literally, Bowen LJ's test would have gone a long way towards suppressing those publications that availed themselves of the techniques of critical journalism, because no one would have wanted to distribute them. These decisions were obviously not what the press wanted; indeed, the decision on distributors' liability prompted booksellers to lobby Parliament in the hope of getting the law changed (see P Mitchell, The Making of the Modern Law of Defamation (Oxford, 2005) 131). But to no avail. These decisions continue to define the role of fault in defamation today.

The judicial attitude to defamation as the law of the press was, therefore, a nuanced and changing one. The protection for literary and other criticism, and for reports of Parliamentary proceedings showed a judicial readiness to give the press a full role in relation to public matters. The judges seem to have felt that the public sphere was the proper place for newspaper involvement, and were ready to adapt the common law to give effect to that view. But the more personal, private matters discussed by the later nineteenth century newspapers did not attract the same kind of judicial sympathy. When such matters were litigated, the judicial response was to tighten the rules, and limit the role of fault as a defence.

\section{CONCLUSION}

The extent to which the nineteenth century law of defamation was a law of the press is, therefore, difficult to encapsulate in simple terms. Large parts of the law developed entirely without reference to press considerations. Where reference was made to the press, it is necessary to separate Parliament and the courts. Throughout the nineteenth century there clearly was a Parliamentary appreciation that the content of the law of defamation should be responsive to the press. But the form that that response took was never uniform. At one end of the spectrum is the 1888 Act, which simply gave journalists what they asked for; at the other was the introduction of the public benefit requirement in New South Wales in 1847 , which gave journalists precisely what they had said they did not want.

The 1881 Act, with its general privilege for the reports of public meetings lay somewhere in between: content journalists wanted, but in a form they disliked. All three statutes could legitimately be described as part of the law "of the press", but that description tends to hide the very different relationships between their contents and the members of the press. 
So far as the courts were concerned, if there is a unifying theme, it is about encouraging certain kinds of journalism (such as literary criticism and reports of Parliamentary proceedings) and discouraging other types by reducing or eliminating defences based on fault. In general, material relating to the public sphere seems to have been protected, whilst matters relating to private life were not. In both cases - both encouragement and discouragement - the method used was the exposition of general common law principle relating to fault standards, which, of course, did not apply only to press defendants. But, even though it was not confined to the press, the principles developed by the courts seem to be appropriately categorised as belonging to the "law of the press", because, although they were not desired by the press, they were a response to the Press, and an attempt to regulate its practices.

The result of these complex interactions between the law of defamation and the press was that the nineteenth century law of defamation was a patchwork. Some of it was what the journalists wanted, some of it was exactly the opposite; some of it was responding to their activities, other parts, such as, for instance, the burden of proof of truth, had a major effect on journalists, but had been designed with no reference to them at all. Yet other parts of the law had no relevance to the press whatsoever: slander and qualified privilege are two of the most striking illustrations of that. The nineteenth century law of defamation, in other words, consisted of a mass of material in which there was no consistent theme, policy or assumption about the role of the press in relation to the content of the law. Different criteria had informed different legal sources at different times; no single criterion had prevailed.

The legacy of this complex nineteenth century position is that today defamation sits rather uncomfortably in media law. It may indeed be invoked against media defendants more often than it is invoked against anyone else, but its rules and principles are derived from a variety of sources, some of no relevance to the media, others based on conflicting assumptions about what the media should do. Nineteenth century defamation law was only partly a law of the press, in a complex way; twenty-first century defamation law, having inherited a mass of nineteenth century rules, inevitably has an equally complex, and ambiguous, relationship with its media users.

- This is the lightly revised text of a public lecture given as part of a series on nineteenth century legal history at the Institute of Advanced Legal Studies, University of London in March 2008. It was first published in the Media and Arts Law Review, and is reprinted here by permission. I would like to thank Professor Michael Lobban for the invitation to contribute to this lecture series.

\section{Paul Mitchell}

Reader in Law, King's College London 